\title{
FIRST SUBSTANTIATED RECORD OF THE BLACK-STRIPED PIPEFISH, SYNGNATHUS ABASTER (ACTINOPTERYGII: SYNGNATHIFORMES: SYNGNATHIDAE), IN THE FRESHWATERS OF BOSNIA AND HERZEGOVINA
}

\author{
Pero TUTMAN ${ }^{1 *}$, Maroje BURIĆ ${ }^{2}$, and Boško SKARAMUCA ${ }^{3}$ \\ ${ }^{1}$ Institute of Oceanography and Fisheries, Split, Croatia \\ ${ }^{2}$ Gorica Sv. Vlaha 61A, 20000 Dubrovnik, Croatia \\ ${ }^{3}$ University of Dubrovnik, Department for Aquaculture, Cira Carića 4, 20000 Dubrovnik, Croatia
}

Tutman P., Burić M., Skaramuca B. 2012. First substantiated record of the black-striped pipefish, Syngnathus abaster (Actinopterygii: Syngnathiformes: Syngnathidae), in the freshwaters of Bosnia and Herzegovina. Acta Ichthyol. Piscat. 42 (3): 259-262.

\begin{abstract}
Although the ichthyofauna of Bosnia and Herzegovina has been relatively well studied, the knowledge remains incomplete. This report confirms the occurrence of the black-striped pipefish Syngnathus abaster Risso, 1827 in the freshwaters of Bosnia and Herzegovina. A sample specimen of the black-striped pipefish was obtained from the Neretva River in Bosnia and Herzegovina in July 2011. The morphometric measurements and meristic counts were taken. Although the black-striped pipefish has previously been reported to exist in this region, the data were not reliable or conclusive. Therefore the finding reported herewith can be considered the first substantiated record from Bosnia and Herzegovina and extends the previously known distribution range for this species into freshwaters.
\end{abstract}

Keywords: pipefish, Neretva River, Bosnia and Herzegovina, first reliable record

The freshwater fish fauna of Bosnia and Herzegovina is characterized by considerable species richness and diversity (Kottelat and Freyhof 2007), and have a significant place in Mediterranean ichthyology due to the presence of numerous endemic species with restricted distribution ranges. The checklist of Vuković (1977) of the fish fauna of Bosnia and Herzegovina includes 108 species, while in a more recent report on the freshwater species of the area lists as many as 118 species (Sofradžija 2009). This increase in the number of species is a consequence of several factors, such as:

- Introduction of exotic species;

- Range extension of the species from the Croatian part of lower Neretva River (previously not recorded in the ichthyofauna of Bosnia and Herzegovina); and

- Description of species new to science (Glamuzina et al. 2011).

However, for small and economically insignificant species such pipefishes, it is often very difficult to assess whether a new finding indicates a real expansion or simply that they had been overlooked previously.

The black-striped pipefish, Syngnathus abaster Risso, 1827 , is a small brown-green pipefish (up to $14 \mathrm{~cm}$ ), with dark or pale spots on the trunk and tail. It is a common species of marine and brackish habitats; probably an amphidromous (Riede 2004), but its migratory behaviour needs verification. The distributional range of this species includes the Mediterranean and Black Seas, and the Atlantic coast northward to southern Biscay (Dawson 1986). It can be found mainly among sand-, mud-, or seagrass beds between depths of 0.5 and $5 \mathrm{~m}$, within the temperature range of $8-24^{\circ} \mathrm{C}$ (Dawson 1986) and is the only species of the family Syngnathidae that has been recorded in the freshwaters in Europe (Kottelat and Freyhof 2007). Although its typical habitats are estuaries and sea coasts (Dawson 1986), some authors have reported its presence far upstream of river mouths into freshwater systems (Movčan 1988, Sekulić et al. 1999, Cakić et al. 2002b, Mastitsky et al. 2010). Despite the presently reported finding, the knowledge of the distribution of pipefishes in freshwaters is still insufficient in many areas of their distributional range. In particular, data on their distribution in Bosnia and Herzegovina are very scarce and based solely on general notes from the Neretva River, which belongs to the Adriatic Sea watershed (Vuković 1977, Sofradžija 2009). Whilst the above-mentioned authors considered the lower Neretva River, in Bosnia and Herzegovina, as a potential distributional area for $S$. abaster, no actual specimens have ever been reported from this area (Kosorić 1978, Kosorić et al. 1983, Mikavica 1998). The only reliable data on its pop-

\footnotetext{
${ }^{*}$ Correspondence: Dr. sc. Pero Tutman, Institut za oceanografiju i ribarstvo, Šetalište Ivana Meštrovića 63, 21000 Split, Croatia, phone: (+385) 21408030, fax: (+385) 358650, e-mail: tutman@izor.hr.
} 
ulation distribution were those for the Neretva River delta in Croatia, provided by Dulčić et al. (2007).

Although the black-striped pipefish has previously been mentioned in the list of the fish fauna of Bosnia and Herzegovina, this paper constitutes the first reliable record there and extends the distribution range of this species into Adriatic river basins.

The Neretva River is at $218 \mathrm{~km}$ long, the longest river in the Adriatic basin, with a source located deeply in the hinterland of Bosnia and Herzegovina. The majority of the river is situated in Bosnia and Herzegovina, while a small lower portion of $22.5 \mathrm{~km}$ in length flows through Croatia, where it discharges into the Adriatic Sea. The lower reaches are notable however, due to the vast delta of the Neretva whose surface area covers a total of $170 \mathrm{~km}^{2}$. The Neretva River basin has recently been recognised as significant in the Mediterranean area for its species richness and high degree of endemism of freshwater fishes (Mrakovčić et al. 1995, Smith and Darwall 2005). Moreover, it is noteworthy that several new fish species have been described from this drainage basin during the last decades (Mrakovčić et al. 1996, Bogutskaya and Zupančič 2003, Kovačić 2005, Buj et al. 2009). The ichthyofauna of the Neretva River comprises a highly diverse fish community composed of 49 species (Mrakovčić et al. 2006).

On 23 July 2011, a single specimen of the blackstriped pipefish (Fig. 1) was collected from the Neretva River in Bosnia and Herzegovina, near the confluence with the Krupa River, a left tributary of Neretva (lat. $43^{\circ} 03^{\prime} 18.88^{\prime \prime} \mathrm{N}$; long. $17^{\circ} 41^{\prime} 48.15^{\prime \prime} \mathrm{E}$; Fig. 2). The distance from the sea was approximately $25 \mathrm{~km}$, while the altitudinal range of the area is $0.0 \mathrm{~m}$. The fish was found accidentally caught in an eel trap from in a water depth of $4 \mathrm{~m}$ in a site densely overgrown by submerged vegetation. The water temperature was $17.2^{\circ} \mathrm{C}$, salinity PSS 0.1 . The sample specimen was kept in $70 \%$ ethanol prior to examination. The sex of the preserved specimen was determined by the presence of a brood pouch, typical of the males of the Urophori, which is located ventrally on the tail and consists of two skin folds that contact medially with their free edges (Silva et al. 2006). Measurements were taken on the left side of specimen using a mechanical calliper to $0.01 \mathrm{~mm}$. Total length (TL, mm), standard length $(\mathrm{SL}, \mathrm{mm})$, and total mass $(\mathrm{BW}, \mathrm{g})$ were also measured. A total of 14 morphometric- and seven meristic characteristics were also recorded (Table 1). Among morphometric ones, 12 characters were expressed as \% of TL. Also, the length ( $\%$ of TL) of a brood pouch was measured and the number of pouch rings counted. The specimen has been preserved in 5-\% buffered formalin and deposited in the Ichthyological Collection of the Institute of Oceanography and Fisheries in Split, Croatia, catalogue number IOR-SynAb 2011.

Description of the Neretvian black-striped pipefish specimen is as follows: body elongate and rather rounded, snout slightly rounded without knobs but with tiny bony ridge on upper surface and on back of head, dorsal profile of head almost linear, eyes rounded and minute, dorsal fin slender with 34 soft rays on 7 rings, pectoral with 11 soft rays, anal with 3 soft rays, caudal with 9 soft rays, anus

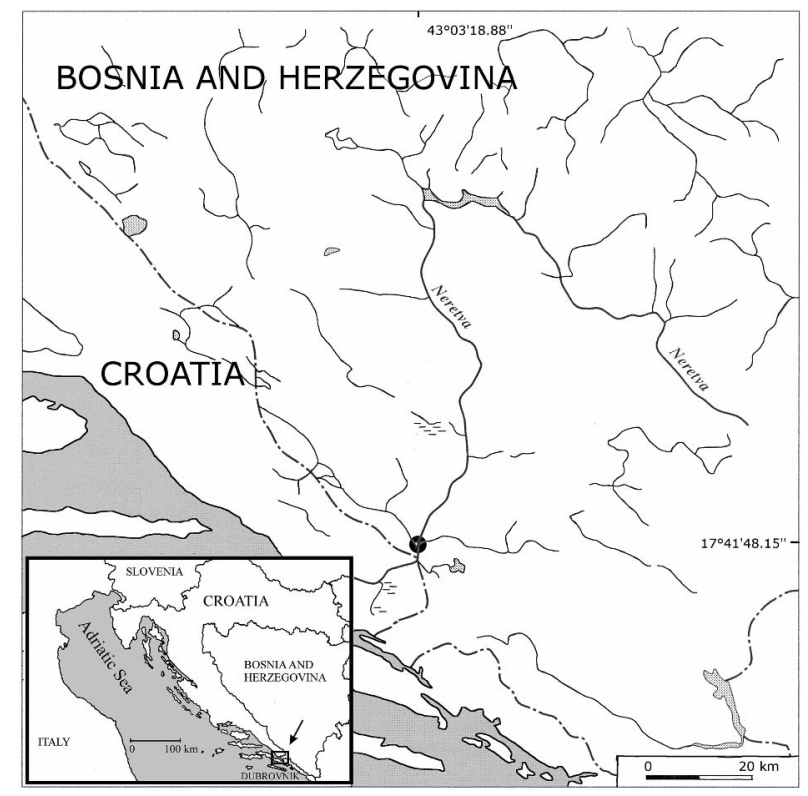

Fig. 2. The Neretva River in Bosnia and Herzegovina with the sampling location (black dot) of the described specimen of black-striped pipefish Syngnathus abaster

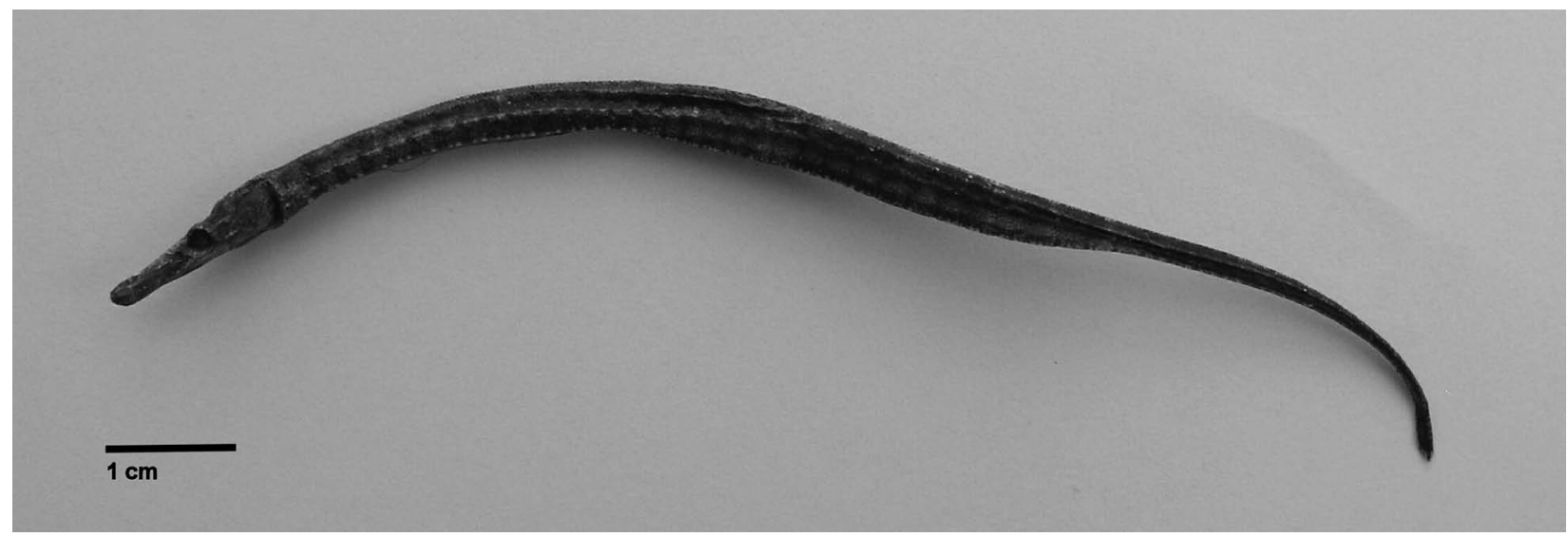

Fig. 1. Black-striped pipefish, Syngnathus abaster $(\mathrm{TL}=114 \mathrm{~mm})$ caught on 23 July 2011 in the lower Neretva River, Bosnia and Herzegovina 
Table 1 tists, dinoflagellates, diatoms, zooplankton, benthic inver-

Morphometric (in mm) and meristic counts of the blackstriped pipefish Syngnathus abaster specimen from the Bosnia and Herzegovina region of the Neretva River

\begin{tabular}{|c|c|c|c|}
\hline & & Parameter & Value \\
\hline \multirow{14}{*}{ 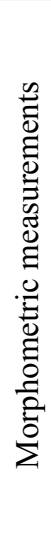 } & $\bar{\Xi}$ & Total length (TL) & 114 \\
\hline & $\Xi$ & Standard length (SL) & 110 \\
\hline & & Maximum body height $(\mathrm{H})$ & 3.22 \\
\hline & & Minimum body height $(\mathrm{h})$ & 0.67 \\
\hline & & Minimum body width (iH) & 2.21 \\
\hline & & Antedorsal distance $(\mathrm{aD})$ & 37.81 \\
\hline & $\Xi$ & Postdorsal distance (pD) & 42.20 \\
\hline & E & Anteanal distance $(\mathrm{aA})$ & 37.82 \\
\hline & $\begin{array}{l}0 \\
0\end{array}$ & Length of dorsal fin basis (ID) & 10.11 \\
\hline & ét & Height of dorsal fin basis (hD) & 1.88 \\
\hline & & Length of anal fin basis (1A) & 0.22 \\
\hline & & Height of anal fin (hA) & 0.58 \\
\hline & & Length of pectoral fin (IP) & 1.55 \\
\hline & & Head length (LH) & 11.87 \\
\hline \multirow{7}{*}{ 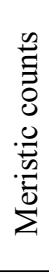 } & & Number of rays in dorsal fin (D) & 34 \\
\hline & & Number of rays in anal fin (A) & 3 \\
\hline & & Number of rays in pectoral fin (D) & 11 \\
\hline & & Number of rays in caudal fin (C) & 9 \\
\hline & & Number of preanal rings (PRA) & 14 \\
\hline & & Number of postanal rings (POA) & 35 \\
\hline & & Number of subdorsal rings (SUD) & 8 \\
\hline
\end{tabular}

located under the beginning of dorsal fin, 14 preanal and 35 postanal rings. Colour light brown to greenish with occasional reddish glow, snout rather brownish with blackish spot before eyes, body with white lines and spots along sides, black spots arranged in line under dorsal base, ventrally whitish.

The specimen can be distinguished from other species of Syngnathidae entering freshwaters in Europe by its cylindrical snout, the length of which is half or less than half of the head length and the depth is 2-4 times in length, 14-15 predorsal rings, caudal rounded and no elongated bump on top of head behind eye. The male brood pouch was identified, occupying 15.27 in \% of SL and the number of pouch rings was 18 . The morphometric- and meristic characteristics are presented in Table 1. The description, morphometric measurements and meristic counts are in agreement with Dawson (1986) and Jardas (1996).

There are several studies concerning records of S. abaster populations in freshwaters, the majority of them in the rivers entering the Black Sea basin. These include findings from the Dnieper River near Kiev, as well as the Dnieper's tributary, the Ros River in Ukraine (Movčan 1988), from the Dnieper in Belarus (Mastitsky et al. 2010) and Danube in Serbia (Sekulić et al. 1999, Cakić et al. 2002a, b). More information about the black-striped pipefish occurrence in the Danube River can be found in Sekulić et al. (1999). It has been suggested that the freshwater population in the Danube ( $900 \mathrm{~km}$ from the river mouth), that they probably resulted from introduction through ship ballast water, originating from the Black Sea (Cakić et al. 2002b). Ballast water has been shown to transport bacteria, pro- tebrates, as well as fishes (Mills et al. 1996).

Although there are some data on the black-striped pipefish distribution in the freshwaters of the Mediterranean, it is difficult to pinpoint the exact locations as they are given only as generalized notes. Kottelat and Freyhof (2007) only indicated a general distribution in the lower reaches of the rivers. S. abaster has previously been reported throughout the estuaries along the South Adriatic coast (Montenegro) (Cakić et al. 2002a) although precise locations were not given. The distribution of the black-striped pipefish in the eastern Adriatic Sea is summarized by Jardas (1996) and Jardas et al. (2008). The latter authors note that the distribution of the black-striped pipefish in the eastern Adriatic coast was poorly known and that they usually inhabit areas with the influence of freshwater. Despite numerous investigations of the freshwater ichthyofauna in Bosnia and Herzegovina during the past 30 years, this fish fauna has not yet been systematically investigated. Although Vuković (1977) and Sofradžija (2009) note the presence of $S$. abaster in Bosnia and Herzegovina, this paper presents the first reliable report of its occurrence. Its occurrence is most likely linked with the populations in the coastal area of Neretva delta in Croatia migrating upstream into suitable habitats.

Although $S$. abaster has no economical value, it has significance from the aspect of ichthyofaunal conservation and overall fish diversity as already stated by Cakić et al. (2002b). The black-striped pipefish is considered as least concerned (LC) in whole distribution area (Anonymous 2011), and data deficient (DD) in Croatia (Jardas et al. 2008). Our observations allow us to confirm the occurrence of $S$. abaster in the waters of Bosnia and Herzegovina. However, in this paper we do not assume that its occurrence represents a recent range expansion. More likely it was the lack of adequate sampling techniques which resulted in the black-striped pipefish being previously overlooked in the freshwaters of Bosnia and Herzegovina. The need for detailed ichthyologic research in order to provide precise data about Bosnia and Herzegovina fish fauna is still required.

\section{ACKNOWLEDGEMENTS}

The authors are thankful to Mr. Mladen Šprlje on finding and providing the specimen and to Dr. Jason Kirby form Liverpool John Moore University for improving the English in the manuscript. We are also thankful to Ministry of Science, Education and Sport of Republic Croatia for financial support (Projects: 001-00130770844, 275-0010501-0856).

\section{REFERENCES}

Anonymous 2011. 2011 IUCN Red list of threatened species.

Bogutskaya N.G., Zupančič P. 2003. Phoxinellus pseudalepidotus (Teleostei: Cyprinidae), a new species from the Neretva basin with an overview of the morphology of Phoxinellus species of Croatia and Bosnia-Herzegovina. Ichthyological Exploration of Freshwaters 14 (4): 369-383. 
Buj I., Vukić J., Šanda R., Perea S., Ćaleta M., Marčić Z., Bogut I., Povž M., Mrakovčić M. 2009. Morphological comparison of bleaks (Alburnus, Cyprinidae) from the Adriatic Basin with the description of a new species. Folia Zoologica 59 (2): 129-141.

Cakić P., Lenhardt M., Mićković D., Pehlivanov L., Mićković B. 2002a. Distribution of Syngnathus abaster in fresh water of Danube and in brackish water along the coast of Black and Adriatic Sea. P. 17. In: 9th International Congress on the Zoogeography and Ecology of Greece and Adjacent Regions; 22-25 May 2002, Thessaloniki, Greece.

Cakić P., Lenhardt M., Mićković D., Sekulić N., Budakov Lj. 2002b. Biometric analysis of Syngnathus abaster populations. Journal of Fish Biology 60 (6): 1562-1569. DOI: $10.1111 / j .1095-8649.2002 . t b 02448 . x$

Dawson C.E. 1986. Syngnathidae. Pp. 628-639. In: Whitehead P.J.P., Bauchot M.L., Hureau J.C., Nielsen J., Tortonose E. (eds.) Fishes of the North-eastern Atlantic and Mediterranean. UNESCO, Paris.

Dulčić J., Tutman P., Matić-Skoko S., Kraljević M., JugDujaković J., Glavić N., Kožul V., Glamuzina B., Bartulović V., Skaramuca B. 2007. A list of Y-O-Y fish species found in the littoral shallows of the Neretva and Mala Neretva estuaries (Eastern Adriatic, Croatian coast). Acta Adriatica 48 (1): 89-94.

Glamuzina B., Tutman P., Pavličević J., Bogut I., Dulčić J. 2011. Bioraznolikost riba Hercegovine. [Fish biodiversity of Herzegovina]. Pp. 119-135. In: Herceg N. (ed.) Međunarodni kolokvij „2010.- godina bioraznolikosti“. Sarajevo: Federalno ministarstvo okoliša i turizma, Sarajevo, Bosnia and Hercegovina. [In Croatian.]

Jardas I. 1996. Jadranska ihtiofauna. [The Adriatic ichthyofauna]. Školska knjiga, Zagreb. [In Croatian.]

Jardas I., Pallaoro A., Vrgoč N., Jukić-Peladić S., Dadić V. 2008. Crvena knjiga morskih riba Hrvatske. [Red book of sea fishes of Croatia.] Ministarstvo kulture, Državni zavod za zaštitu prirode, Republika Hrvatska, Zagreb. [In Croatian.]

Kosorić Đ. 1978. Sastav populacije riba Hutova blata. [The composition of the Hutovo blato fish population.] Godišnjak Biološkog instituta Univerziteta u Sarajevu 31: 69-81. [In Serbo-Croatian/Croato-Serbian.]

Kosorić Đ., Vuković T., Kapetanović N., Guzina N., Mikavica D. 1983. Sastav naselja riba rijeke Neretve u Bosni i Hercegovini. [The composition of the Neretva River fish population.] Godišnjak Biološkog instituta Univerziteta u Sarajevu 36: 117-129. [In Serbo-Croatian/Croato-Serbian.]

Kottelat M., Freyhof J. 2007. Handbook of European Freshwater Fishes. Kottelat, Cornol, Switzerland and Freyhof, Berlin, Germany.

Kovačić M. 2005. A new species of Knipowitschia (Gobiidae) from Dalmatia, Croatia. Cybium 29 (3): 275-280.

Mastitsky S.E., Karatayev A.Y., Burlakova L.E., Adamovich B.V. 2010. Non-native fishes of Belarus: diversity, distribution, and risk classification using the Fish Invasiveness Screening Kit (FISK). Aquatic Invasions 5 (1): 103-114.

DOI: 10.3391/ai.2010.5.1.12

Mikavica D. 1998. The specific freshwater ichthyofauna of the hydrographic region of Bosnia and Herzegovina. Ichthyologia 30 (1): 31-38.

Mills E.L., Strayer D.L., Scheurell M.D., Carlton J.T. 1996. Exotic species in the Hudson River basin: A history of invasions and introductions. Estuaries 19 (4): 814-823.

Movčan Y.V. 1988. Fauna Ukrainy (Ryby). [Fauna of Ukraine (Fishes).] Naukova Dumka, Kiev. [In Russian.]

Mrakovčić M., Brigić A., Buj I., Ćaleta M., Mustafić P., Zanella D. 2006. Crvena knjiga slatkovodnih riba Hrvatske. [Red book of freshwater fishes of Croatia.] Ministarstvo kulture, Državni zavod za zaštitu prirode, Republika Hrvatska, Zagreb. [In Croatian.]

Mrakovčić M., Kerovec M., Mišetić S., Schenider D. 1996. Description of Knipowitschia punctatissima croatica, (Pisces, Gobiidae), a new freshwater goby from Dalmatia, Croatia. Pp. 311-319. In: Kirchhofer A., Hefti D. (eds.) Conservation of endangered freshwater fish in Europe. Birkhäuser Verlag, Basel, Switzerland.

Mrakovčić M., Mišetić S., Povž M. 1995. Status of freshwater fish in Croatian Adriatic river systems. Biological Conservation 72 (2): 179-185.

Riede K. 2004. Global register of migratory species-From global to regional scales. Federal Agency for Nature Conservation, Bonn, Germany.

Sekulić N., Cakić P., Lenhardt M., Vučić D., Budakov Lj. 1999. Short-snouted pipefish Syngnathus abaster (Acanthopterygii: Syngnathidae) in the Yugoslav section of the Danube. Ichthyologia 31 (1): 79-82.

Silva K., Monteiro M., Vieira N., Almada V.C. 2006. Reproductive behaviour of the black-striped pipefish Syngnathus abaster (Pisces; Syngnathidae). Journal of Fish Biology 69 (6): 1860-1869. DOI: $10.1111 / j .1095-8649.2006 .01229 . x$

Smith K.G., Darwall W.R.T. 2006. The status and distribution of freshwater fish endemic to the Mediterranean basin. IUCN, Gland, Switzerland and Cambridge, UK.

Sofradžija, A. 2009. Slatkovodne ribe Bosne i Hercegovine. [Freshwater fishes of Bosnia and Herzegovina.] Vijeće Kongresa bošnjačkih intelektualaca, Sarajevo. [In Bosnian.]

Vuković T. 1977. Ribe Bosne i Hercegovine. [Fishes of the Bosnia and Herzegovina]. IGKRO Svjetlost, Sarajevo. [In Serbo-Croatian/Croato-Serbian.]

Received: 16 March 2012

Accepted: 26 June 2012 Published electronically: 30 September 2012 